\title{
Applying Cognitive-Behavioral Therapy to Help Survivors of Dating Violence: A Pilot Study
}

\author{
Stefanus Perangin-Angin ${ }^{1}$, Sutarto Wijono ${ }^{2}$, Arianti Ina Restiani Hunga ${ }^{3}$ \\ 1,2Faculty of Psychology, Universitas Kristen Satya Wacana ${ }^{3}$ Faculty of Social Science \\ Universitas Kristen Satya Wacana
}

Submitted 11 May 2020 Accepted 10 February 2021 Published 26 April 2021

\begin{abstract}
Research from National Commission on Elimination of Violence against Women found that dating violence was ranked second after domestic violence in terms of number of cases reported in 2018 in Indonesia. Post-Traumatic Stress Disorder (PTSD) was one of the consequences that dating violence survivors experienced. Cognitive-Behavioral Therapy (CBT) had been proven effective to treat PTSD in intimate partner violence survivors. However, there was no prior research publication investigating the effectiveness of CBT for dating violence survivors in Indonesia. This research aimed to apply CBT to help treating PTSD symptoms in women with dating violence experiences. CBT was delivered individually for six sessions to four participants. This research used mixed-method design with quantitative and qualitative data collection and data analysis components. PTSD Checklist for DSM-5 was used to measure PTSD symptoms at pre- and post-treatment. The results showed that all participants had reduction in PTSD symptoms at post-treatment. However, two participants still met the criteria for PTSD because their post-treatment scores were still above remission cut-off scores. Future research can focus on helping survivors to gain resiliency, psychological well-being, self-esteem and regaining meaning of life back after having dating violence experiences.
\end{abstract}

Keywords: cognitive-behavioral therapy; dating violence; intimate partner violence; post-traumatic stress disorder; violence against women

Dating violence (DV) is a type of violence that can occur in early adulthood relationship. According to Indonesian National Commission on Elimination of Violence against Women (2018), women often become victims in the dating relationship and are more vulnerable to the infliction of violence in dating or intimate relationship. DV belongs to the intimate partner violence (IPV) cluster (Jennings et al., 2017) and in the context of the current research, the main focus is violence incidences that are inflicted to women. In general, the frequencies of violence against women are increasing globally (World Health Organization, 2013). In United States, violence against women and IPV has become a major and complex public health issue. aIn one of the major national surveys in United 
States, the survey found that 1 in 4 women in that country will experience violence incidence from their male partner at least once in their lifetime (Breiding et al., 2008; Centers for Disease Control and Prevention, 2014). Out of all women experiencing IPV in United States, $30 \%$ of them reported experiencing physical violence from their partner, $10 \%$ of the women reported experiencing sexual abuse or violence from their partner, and $48 \%$ of them reported experiencing psychological violence from their partner (Breiding et al., 2014). Mental health consequences of IPV in United States are also becoming a burden to the healthcare of the nation (Rivara et al., 2007). Another research in the States found that, as estimates, the direct healthcare costs of IPV and indirect costs of IPV such as loss of productivity and income are US\$ 8,3 billion (Max et al., 2004).

Findings in other nations and regions are also indicating that violence against women has become a major public health concern. Violence against women has a high prevalence in developing regions such as in South East Asia region (37. 7\%) and Africa region (36.6\%) (World Health Organization, 2013). In Thomson Reuters Foundation Annual Report, Indonesia ranked third after India and Saudi Arabia as a nation with high incidence and percentage of violence against women (Baldwin, 2012). In fact, data collected by Indonesian National Commission on Elimination of Violence against Women indicated that from 2014 to 2017, there was a rise in number of cases of violence against women reported from 293,220 cases to 348,446 cases (National Commission on Elimination of Violence against Women, 2015, 2016, 2017, 2018). According the National Commission's partner institutions, dating violence (DV) against women ranked second after domestic violence in terms of number of cases reported in Indonesia in 2018 (National Commission on Elimination of Violence Against Women, 2018). However, this number might be an underestimation because this phenomenon might be an iceberg phenomenon where the tip of the iceberg is visible on the surface, but most of its parts are hidden in the water. Likewise, many of intimate partner violence, domestic violence, and dating violence cases against women are left unreported to government (Carrell \& Hoekstra, 2012; Huecker \& Smock, 2019).

DV itself is defined as an action that is done intentionally to hurt dating partner and is done in order to gain and maintain control and power over the partner (Murray, 2013). The action could be in a form of coercion, physical, sexual, verbal or emotional abuse. This act of violence and abuse can occur throughout dating relationship and can escalate before the end of dating relationship (Murray, 2013). The consequences of DV are also serious. As a result of the violence, psychologically, the victim often felt powerless and helpless over her situation (Cougle et al., 2009). These feelings would result in low level of motivation and energy, and these would lead to the inability of the woman to detect, identify, and avoid potential situations that could lead to the occurrence of violence (Cougle et al., 2009). Moreover, the victims of DV can also suffer from stress, insomnia, anxiety, poor concentration, depression, and low self-esteem (Kristoper et al., 2019; Perangin-Angin et al., 2019).

Because of these multi-factorial problems, women who become victims of DV often developed symptoms of post-traumatic stress disorder (PTSD) (Cougle et al., 2009; 
Iverson et al., 2011). In terms of risk factors, compared to DV survivors that were not developing PTSD symptoms, DV survivors who develop PTSD symptoms were usually more likely to experience adversity or maltreatment during childhood (e.g. child neglect, witnessing violence, and having physical, psychological, or sexual abuse), and more likely to experience peer victimization, sexual harassment by peers and have affiliation with deviant peers during adolescence years (Hébert et al., 2019). Furthermore, according to Exner-Cortens et al. (2013), DV victimization in adolescence would predict the occurrence of IPV victimization and involvement in unstable and violent relationship in the subsequent intimate partner relationship (i.e. including dating relationship). These exposures and experiences would help to create certain negative and unhelpful cognitive schemas in the individuals about dating and intimate partner relationship (Calvete et al., 2018; Miller et al., 2018). In terms of protective factors, parental bonding, closeness, and support from parents during childhood could decrease future victimization risk from a romantic partner (Hébert et al., 2019). Specifically, bonding, closeness, and support from parents would nurture and promote a sense of self-worth in the individual, and in turn, this protective factor would help to decrease the likelihood of the individual's involvement in abusive relationship in the future (Alleyne-Green et al., 2016). Secondly, effective parental monitoring, effective conflict resolution skills, open communication, and consistent discipline from parents during childhood have been linked with the individual's DV risks reduction during adolescence and young adulthood (Vézina et al., 2015). Thirdly, having a supportive network of friends and having close friends that are modelling and influencing pro-social behavior could also become protective factors that would decrease the likelihood of involving in an abusive dating or intimate relationship (Folger \& Wright, 2013; Han \& Margolin, 2016; Vézina et al., 2011). These protective factors would help to create a helpful and healthy schemas about self, others, the world, and the future in the individual and specifically, about what to expect in a healthy dating or intimate relationship.

However, if the risk factors continue to become more prevalent in one's life, it would affect the mental health condition of the person and it would increase the likelihood of the person's experiencing violence in dating relationship and subsequently having PTSD symptoms. Moreover, in one of the research about IPV and DV, the researchers found that if the victims had symptoms of PTSD, this could significantly increase the risk for the women to re-experience violence victimization from their partner (Krause et al., 2006; Kuijpers et al., 2012). This re-victimization could also be in a form of psychological, verbal, and emotional violence (Bell et al., 2008). Consistent with many empirical research, having symptoms of PTSD can increase the risk of DV and IPV in women because of the emergence of symptom called emotional numbing in the victims (Iverson et al., 2011). This symptom is one of the characteristics of PTSD and consists of emotional suppression and unwillingness to feel any feelings or emotions (MessmanMoore \& Long, 2003). Emotional numbing symptom could hinder woman's ability to detect and respond accordingly to the possibility of violence (Messman-Moore \& Long, 2003). 
In terms of intervention to treat women experiencing IPV, therapies from CognitiveBehavioral Psychotherapies cluster such as Cognitive-Behavioral Therapy (CBT) has been used and researched to help alleviate survivors ${ }^{\prime}$ clinical symptoms such as PTSD (Bisson et al., 2007; Foa et al., 2005; Iverson et al., 2011; Resick et al., 2008; Trabold et al., 2018). The results indicated that $\mathrm{CBT}$ was effective in reducing symptoms of PTSD in women with IPV experiences (Crespo \& Arinero, 2010; Iverson et al., 2011; Johnson et al., 2011; Reed \& Enright, 2006; Resick et al., 2008; Trabold et al., 2018). The specific core ingredient which makes CBT effective in reducing PTSD symptoms in women with IPV experiences is its cognitive techniques (such as cognitive disputation, cognitive restructuring, or examining the evidence techniques) that helped to change women's negative core beliefs and unhelpful thinking patterns about IPV experiences that they experienced (Iverson et al., 2011; Trabold et al., 2018). Specifically, cognitive techniques in CBT are effective in changing negative thinking patterns such as "If my partner leaves me then my life will be difficult and empty, therefore I choose to endure this even though I am hurt and wounded", "He (the perpetrator) hurt me because he loved me", and "I (the victim or survivor) am definitely a worthless and useless person, because I failed to meet my partner's expectations", that commonly found in negative automatic thoughts and core beliefs of women with IPV experiences (Iverson et al., 2011; Perangin-Angin et al., 2019; Trabold et al., 2018). The researcher chose CBT to be implemented to help DV survivors instead of other therapies in Cognitive-Behavioral Psychotherapies cluster such as Cognitive Processing Therapy (CPT), Acceptance and Commitment Therapy (ACT), or Rational Emotive Behavioral Therapy (REBT) because of its emphasis on targeting and changing pre-existing negative beliefs about the self, others, the world, and the future (e.g. see Ehlers \& Clark, 2000). These pre-existing negative beliefs can be in the form of negative appraisals of the traumatic experiences and traumatic experiences sequelae such as misinterpretations of PTSD symptoms and exaggeration of the sense of current threat (Dunmore et al., 2001; Ehlers \& Clark, 2000). Moreover, these beliefs and negative appraisals would sustain and perpetuate PTSD because it helps to produce negative feelings about the trauma and its subsequent maladaptive coping strategies to cope with the symptoms (Ehlers \& Clark, 2000). These, in turn, would maintain the PTSD symptoms in vicious cycle and exacerbate the condition of the victims. In order to break the cycle, CBT is the most appropriate treatment because the core focus of the treatment is to target and change maladaptive cognitions about self, others, the world, and the future (Iverson et al., 2011; Johnson et al., 2011). Compared to CBT, CPT is a specific form of CBT with an additional written trauma account component where the client is encouraged and asked to write and share the written detail of traumatic experiences with the therapist ( Resick et al., 2016). However, several studies about CPT indicated that CPT without written account component was as effective as CPT with written account component (Haller et al., 2016; Resick et al., 2008). CPT protocol without a written-account component is very similar with CBT protocol, with an emphasis on targeting maladaptive cognitions and changing it with cognitive techniques (Resick et al., 2008). Secondly, compared to ACT, the major difference/distinction between ACT and CBT is about the tenet/idea of 
challenging one's thoughts and beliefs. According to Hayes et al. (1999), ACT focuses on changing one's relationship with their thoughts and emotions and does not include targeting and challenging one's distorted beliefs. Lastly, REBT has very similar approach with CBT and both have the same emphasis on the connection of human emotion, behavior and thinking. However, the researcher chose CBT over REBT because the fact that CBT has larger body of research attesting to its efficacy for a wide range of psychiatric problems (Beck \& Dozois, 2011).

Several studies in other countries have demonstrated the efficacy of CBT to be applied for DV victims or survivors. In their study, Rizzo et al. (2018) applied a CBTbased program for DV prevention (Date SMART) to a sample of adolescent girls (ages 14 17) with prior physical DV experiences. The researcher, then, compared the CBT-based program with a knowledge-only comparison group. The Date SMART group was effective in reducing DV involvement at the 9-month follow-up period. However, contrary to the researcher expectation, the comparison group also had clinically significant reduction in DV involvement. In other research by Sánchez-Jiménez et al. (2018), the researcher conducted a DV prevention program aimed at adolescents in Spain. Comparing an experimental group with a control group, the results showed that the program did not give significant impact on physical, psychological or online dating aggression and victimization. However, in terms of schemas/beliefs, the program was effective at modifying maladaptive concepts about romantic love and also effective in improving participants' self-esteem and anger regulation (both related to changes in cognitions).

However, to the best of author knowledge, no prior publication on investigating the effectiveness of CBT to help DV survivors in Indonesia yet. As the current research aimed to treat and help women with DV experiences in Indonesia, this will become the novelty of the current research. Although the characteristics of IPV and DV are quite similar and DV is a specific form of IPV, there are main differences between IPV and DV. The main differences are in the characteristics of women experiencing violence. Compared to women experiencing IPV, women with DV experiences usually are younger, less established financially, more prone to peer pressure, having lower level of socio-economic status (Shorey et al., 2008). Thus, approaches of CBT for DV survivors would have specific differences compare to CBT for IPV survivors. Specifically, first, the dynamics of dating relationship context would differ from the dynamic of intimate partner relationship context. Secondly, the content of cognitions that would be targeted in CBT would be different as well. In the former, the focus of cognition would be on jealousy, feeling ignored, feeling unappreciated or dispute/quarrel over financial issues. While the latter (IPV) would usually focus on issues such as safety of extended family, safety of kids, safety of self or the victim, or emotional numbing due to prolonged IPV exposures (Ager, 2020). However, there are some issues that are overlapping between DV and IPV problems such as the helplessness of victim, perpetrator's control over victim, physical and emotional hurt, perpetrator reactivity or unstable mood and negative attitudes about the opposite sex (Ager, 2020). 
Being a feasibility study, this research aimed to investigate the effectiveness of CBT in reducing PTSD symptoms in survivors of DV. Based on the theoretical review above, we hypothesized that the current research's CBT protocol would be effective in helping to reduce PTSD symptoms in women with DV experiences.

\section{Method}

This study employed a mixed-method approach using both quantitative method and qualitative method of data collection and analysis (Johnson et al., 2007). Specifically, quantitative method was employed in the first phase of the study, followed by qualitative method in the second phase of the study. Prior to conducting the study, ethical clearance was reviewed and granted by Satya Wacana Christian University's Human Research Ethical Committee in January 2019. In this section, recruitment and selection of participants, instrument that was used in the study, intervention or treatment procedure of current study, and the design and analysis of study would be further elaborated.

\section{Participants}

Research participants were recruited using purposive sampling method through, firstly, administering short screening questionnaire to 160 students in undergraduate psychology and undergraduate sociology classes in Satya Wacana Christian University at Salatiga in order to identify potential participants from the campus. Secondly, the researchers also used methods such as spreading information about the research through word of mouth, to close friends, and to classmates in order to identify and recruit potential participants in Salatiga. Through these two methods, the researchers found six women who were eligible to participate in this research, however only four women agreed and gave their consent to participate in this research. All participants had separated from their dating partners and had experienced dating violence from their partners. In order to be eligible for this study, the participants' must have range of age between 18 to 30 years old, must have prior experiences of violence in dating relationship from their dating partners, must have minimum scores of 31 to 33 in Post-Traumatic Stress Disorder Check List for Diagnostic and Statistical Manual of Mental Disorder $-5^{\text {th }}$ Edition (PCL-5) instrument, were not currently undergoing other treatment or psychological intervention, and must be willing to give consent and to become participants in the research. During the research, the researcher provided transportation from participants' place to the place for CBT session to each participant. After the research was finished, as reward for participating in the research, the researcher gave a set of souvenirs as token of appreciation to each participant.

\section{Instrument}

PTSD symptoms were measured using PTSD Checklist for DSM-5 (PCL-5) that was developed by Weathers et al. (2013). PCL-5 has four main dimensions which were intrusive symptoms related to the traumatic events, avoiding things that reminded the person to the traumatic events, changes in cognition and mood, and increased arousal 
levels. This self-report instrument has 20 items, and each item measures the intensity of each symptom ranging from 0 (not at all) to 4 (extremely often), with higher scores indicating that the symptom has higher intensity level. This instrument has a good level of reliability and validity when tested on both general population and clinical population (Blevins et al., 2015; Bovin et al., 2016). According to study from Blevins et al. (2015), the internal consistency of PCL-5 was strong (Cronbach's $\alpha=0.94$ ) and this instrument also has strong test-retest reliability $(r=0.82)$. For the current study, the researcher consulted PCL-5 instrument to two experts (a psychology lecturer and a clinical psychologist) in order to check for translation suitability and accuracy from English to Bahasa Indonesia. After this step, the researcher tested the instrument to 34 female undergraduate university students in Salatiga with mean of age 20 years old and obtained an internal consistency of 0.89. The cut-off score in PCL-5, in order to be included as having clinical symptoms of PTSD, was from 31 to 33 . The highest possible score, if the participant chose 4 or extremely often on each item in the scale, was 80 (Weathers et al., 2013). Additionally, interpretation of scores and changes of scores should be handled carefully. In order to measure change using PCL-5 instrument, it was suggested that a 5 to 10 point change represented a reliable change (i.e.; change not due to chance) and a 10 to 20 point change represented a clinically significant change (Weathers et al., 2013).

\section{Intervention and procedure}

The CBT intervention was done in Salatiga and was started on May 2019 until September 2019. CBT focused on three core components which were physiological, cognitive, and behavioral components ( Beck, 2011). The CBT protocol in this research was designed to help participants in alleviating their PTSD symptoms by firstly, changing their cognitions about the DV experiences and secondly, by changing their current behavioral responses to the past DV experiences. The participants in this research would receive individual therapy session for 45 to 60 minutes per week, in accordance with the current research CBT protocol. There were six therapy sessions in the protocol, and the therapy sessions were given individually to each participant. The therapist was a final year Master level psychology student that was supervised by a licensed clinical psychologist, and she (the psychologist) had 10 years clinical experiences in the field of clinical psychology, treating various mental health issues and symptoms including Post-Traumatic Stress Disorder (PTSD), and was familiar and experienced in using CBT intervention. In order to ensure that CBT intervention was delivered professionally by a student-therapist, the clinical psychologist gave prior training for 5 sessions about the steps on CBT interventions to the student-therapist. After that, the clinical psychologist closely monitored the progress of every session by requiring the therapist to give report to the psychologist prior and after giving a therapy session. In terms of relation with the researcher, the therapist came from the same research group/team with the researcher at the institution/university.

Generally, there were three phase of Cognitive-Behavioral Therapy (CBT) intervention for helping survivors of DV, namely, early phase, middle phase, and final phase. In the early phase, the therapist gave explanation about the fundamentals of CBT, PTSD 
symptoms, and how this therapy could help to alleviate symptoms of psychological trauma or PTSD. These explanations were essential to be given in the early phase of therapy because the participants needed to know and understand about the characteristics of the therapy and symptoms of PTSD that they experienced before they proceeded into more in-depth therapy sessions (Barlow, 2008). Next, in the middle phase of the therapy, the therapist introduced sets of skills and techniques that were derived from cognitive and behavioral aspects of CBT. Based on previous research on Intimate Partner Violence (Iverson et al., 2011; Resick et al., 2016), the therapist chose to firstly focus on the cognitive component of the therapy by targeting on the maladaptive cognitions and irrational beliefs of participants before giving behavioral therapy or intervention. In the middle phase of therapy, the therapist introduced and taught the techniques in sequence, starting from introducing and teaching mood and thought monitoring technique, explaining about cognitive distortions and automatic thoughts, introducing cognitive disputation techniques through collaboratively working and practicing on thought-change record exercise and examining the evidence exercise. The education and techniques were introduced gradually and one step at a time, so that the information that were given to the participants could be remembered and understood well by them. This approach was in line with approach and research from Barlow (2008) and Beck (2011). Next, after giving cognitive interventions, in the final phase of therapy, relaxation technique was given to the participants as part of behavioral component of CBT intervention.

Table 1.

CBT Protocol to Help Survivors of Dating Violence

\begin{tabular}{|c|c|}
\hline Session & CBT Protocol per Session \\
\hline Initial Interview & Initial interview regarding DV experiences from participants \\
\hline Pre-Intervention Session & $\begin{array}{l}\text { Need Assessment; Administration of PCL-5 at pre-intervention (pre- } \\
\text { test) }\end{array}$ \\
\hline Session 1 & $\begin{array}{l}\text { Explanation about PTSD symptoms and connection between } \\
\text { thinking, emotion, and behavior }\end{array}$ \\
\hline Session 2 & $\begin{array}{l}\text { Continuation of connection between thinking, emotion, and behavior; } \\
\text { Introduction to mood and thought monitoring }\end{array}$ \\
\hline Session 3 & $\begin{array}{l}\text { Continuation of mood and thought monitoring; Introduction to } \\
\text { cognitive distortions and automatic thoughts }\end{array}$ \\
\hline Session 4 & $\begin{array}{l}\text { Continuation of cognitive distortions and automatic thoughts; } \\
\text { Introduction to cognitive disputation }\end{array}$ \\
\hline Session 5 & Continuation of cognitive disputation \\
\hline Session 6 & Application of relaxation techniques \\
\hline Post-Intervention Session & $\begin{array}{l}\text { Administration of PCL-5 at post-intervention (posttest); Research } \\
\text { reflection }\end{array}$ \\
\hline
\end{tabular}

Note: In cognitive disputation, participants learned to dispute their maladaptive cognitions through examining the evidence and thought-change record exercises. Relaxation techniques such as deep breathing and progressive muscle relaxation was introduced to participants by the therapist and the therapist encouraged participants to practice the technique regularly at home every day at their own pace. 
Lastly, research reflection from participants and therapist was done in order to discuss which aspect of the therapy that was most helpful to participants, which progress or improvements that were most felt by participants and the new helpful cognitions that the participants have now. The summary of the CBT protocol can be seen in Table 1 above.

\section{Research design and analysis}

The current research used a mixed-method design with quantitative and qualitative methods of data collection and analysis respectively (Johnson et al., 2007). This research was a feasibility pilot study. In the quantitative phase of the study, a small-N, AB design was employed (Todman \& Dugard, 2001). Baseline measure was collected at the preintervention session and treatment measure was collected at post-intervention session. Secondly, in the qualitative phase of the study, a semi-structured interview was conducted to each participant individually in order to understand the process of therapeutic change.

In the analysis phase, differences in individual level were analyzed using small-N approach. Quantitative data was presented in graphs and for visual inspection of the level, trend, and slope for each participant. For the qualitative phase of the study, the qualitative data was transcribed and analyzed using thematic analysis (Braun \& Clarke, 2006). Thematic analysis would follow these steps: familiarization of the data (i.e.; verbatim transcription), generating initial codes, searching for themes, reviewing themes, defining and naming themes, and producing the report (Braun \& Clarke, 2006).

Secondly, qualitative analysis was also done through comparison of pre-test and post-test scores of PCL-5, in the form of observations during the CBT intervention process, interviews with participants, and evaluation of the results from participants' worksheets during the implementation of the CBT intervention.

\section{Results}

\section{Initial results}

Initial interview and pre-test of participants indicated that all participants met criteria for PTSD, with one participant was in mild clinical range and three other participants were in moderate clinical range. The participants' range of age were 19 to 28 years old. Based on the results of individual initial interview to the research participants, it was found that participants DV problems and experiences as can be seen in Table 2.

Dating violence (DV) problems that were experienced by participants were varied greatly; from verbal violence such as receiving harsh, abusive, and hurtful comments or words from the perpetrators, to physical violence such as being beaten and kicked without apparent reason. Although all participants had separated from their partners, these verbal, emotional, physical and sexual violence that were experienced by participants during their dating period contributed to the experiences of post-separation 
negative consequences in their cognitions, emotions, and behavior. Table 3 summarizes maladaptive cognitions as a result of DV experiences and the consequences of DV to participants' or survivors' emotion and behavior. These maladaptive cognitions and consequences to emotion and behavior were derived, initially, in need assessment session and then uncovered further in CBT session 2 to session 4 .

Table 2.

Dating Violence (DV) Problems Conducted by Perpetrators to Participants

\begin{tabular}{|c|c|c|c|c|}
\hline Name & Verbal DV & Emotional DV & Physical DV & Sexual DV \\
\hline W & $\begin{array}{l}\text { Abusive words; } \\
\text { Harsh language }\end{array}$ & $\mathrm{W}$ was being cheated on & $\begin{array}{c}\text { Beaten and kicked } \\
\text { for no apparent } \\
\text { reason }\end{array}$ & $\begin{array}{l}\text { Forced to have } \\
\text { intercourse but still } \\
\text { can refuse } \\
\text { perpetrator }\end{array}$ \\
\hline$X$ & $\begin{array}{l}\text { Perpetrator } \\
\text { denigrated } \\
\text { religious belief of } \\
\text { X; Hurtful } \\
\text { comments }\end{array}$ & $\begin{array}{l}\text { Conflict because } \\
\text { perpetrator is too } \\
\text { possessive; Conflict } \\
\text { because of differences in } \\
\text { religious beliefs }\end{array}$ & $\begin{array}{l}\text { X's cell phone was } \\
\text { slammed; X was } \\
\text { slapped during } \\
\text { conflict escalation }\end{array}$ & None \\
\hline $\mathrm{Y}$ & $\begin{array}{l}\text { Abusive words; } \\
\text { Harsh language }\end{array}$ & $\begin{array}{l}\text { Y was being cheated on; } \\
\text { Perpetrator still tried to } \\
\text { relate to Y despite } \\
\text { having an affair with } \\
\text { another woman }\end{array}$ & None & None \\
\hline Z & $\begin{array}{l}\text { Abusive words } \\
\text { from the } \\
\text { perpetrator }\end{array}$ & $\begin{array}{l}\text { Perpetrator was easily } \\
\text { jealous and very } \\
\text { possessive; } Z \text { was forbid } \\
\text { to talk or interact with } \\
\text { people other than the } \\
\text { perpetrator }\end{array}$ & $\begin{array}{l}\text { Being kicked; Beaten } \\
\text { with wooden } \\
\text { hangers; laptop and } \\
\text { cell phone were } \\
\text { slammed by the } \\
\text { perpetrator }\end{array}$ & Undisclosed \\
\hline
\end{tabular}

Table 3.

Participants Maladaptive Cognitions and DV Consequences to Emotion and Behavior

\begin{tabular}{lllll}
\hline Aspects & \multicolumn{1}{c}{ Participant 1 (W) } & Participant 2 (X) & Participant 3 (Y) & Participant 4 (Z) \\
\hline Maladaptive & "Generally, all men & "I am crushed & Unfulfilled hopes & Thoughts of regret \\
cognitions & are rude to women"; & and broken, & and expectations & and bitterness; \\
and thinking & Increased self- & because of this & about dating; & Unfulfilled dating \\
patterns & criticism; Avoiding & conflict"; & Thought about & expectations; \\
& any thought that & Expectations & difficulties to let & Increased self- \\
& could remind her of & about 'ideal' & go of and forgive & criticism; Avoiding \\
& DV experiences & dating & the perpetrator & any thought that \\
& & relationship was & & could trigger \\
& & unfulfilled & & reminder of DV \\
\hline
\end{tabular}




\begin{tabular}{lllll}
\hline Aspects & \multicolumn{1}{c}{ Participant 1 (W) } & Participant 2 (X) & Participant 3 (Y) & Participant 4 (Z) \\
\hline Consequence & Be very vigilant when & Angry feeling & Feeling of & Feeling of fear of the \\
s to emotion & interacting with men; & toward & sadness; Feeling & perpetrator; \\
and behavior & Having sad feeling; & perpetrator; & of hurt; difficulty & Avoiding \\
& Disappointed; Feeling & feeling of hate & to sleep; frequent & perpetrator by \\
& of hurt; Avoiding & toward self and & crying; unable to & moving frequently \\
& situations that could & perpetrator; & focus; difficulty & from one residence \\
& remind her of DV & feeling of sadness & to regulate & to another \\
& experiences & and hurt & emotions & \\
\hline
\end{tabular}

\section{Results of intervention}

There was one hypothesis that would be tested in this research. The hypothesis testing was conducted by, firstly, measuring and interpreting the changes in scores of PCL-5 before CBT interventions (pre-test) and after CBT interventions (post-test). Secondly, the changes of PCL-5 scores were also being checked from and validated through therapist's assessment of cognition and behavioral changes throughout the therapy sessions. This was done through analyzing participants responses in CBT worksheets (i.e.; mood and thought monitoring, thought-change record, and examining the evidence worksheet) and observing changes in participant's non-verbal gestures and facial expressions throughout every session. Table 4 summarizes the results of PCL-5 scores before and after six individual CBT interventions.

Table 4.

PCL-5 Pre-test and Post-test Results of Participants

\begin{tabular}{llcclcl}
\hline No & Participant & Age & $\begin{array}{c}\text { Pre-test } \\
\text { Scores }\end{array}$ & Category & $\begin{array}{c}\text { Post-test } \\
\text { Scores }\end{array}$ & \multicolumn{1}{c}{ Category } \\
\hline 1 & W & 20 & 51 & Moderate Range & 23 & Normal Range \\
2 & X & 19 & 51 & Moderate Range & 38 & Mild Range \\
3 & Y & 26 & 32 & Mild Range & 7 & Normal Range \\
4 & Z & 28 & 51 & Moderate Range & 37 & Mild Range \\
\hline
\end{tabular}

Furthermore, the negative maladaptive cognitions and its repercussions were the basis of doing cognitive intervention such as CBT. Because the core feature of CBT intervention was mainly to change the maladaptive cognitions that caused disturbances and dysfunctions in thinking patterns, emotions and behavior (J. Beck, 2011). In the process of doing CBT intervention, based on the CBT protocol described above, maladaptive cognitions of all participants were step-by-step changed into new positive and adaptive cognitions. The processes of cognitive and thinking changes of participants will be discussed in detail and in light of previous literature in the discussion section. The summary of new adaptive cognitions and progress of improvements from participants after all CBT interventions were given can be seen in Table 5 .

In overall, the CBT intervention provided a positive impact to all participants in the form of improvement in symptoms of PTSD experienced by the participants or survivors. Nevertheless, there were variations and differences in improvements of symptoms in the 
survivors. Two participants (participant $1 \& 3$ ) achieved remission from PTSD symptoms and two other participants (participant 2 \& 4) improved but were still in mild range condition of PTSD symptoms. This will be further discussed in the discussion section of this research article.

Table 5.

Participants New Adaptive Cognitions and Post-Therapy Progress of Improvements

\begin{tabular}{|c|c|c|c|c|}
\hline Aspects & $\begin{array}{l}\text { Participant } 1 \\
\text { (W) }\end{array}$ & Participant 2 (X) & Participant 3 (Y) & Participant 4 (Z) \\
\hline $\begin{array}{l}\text { New adaptive } \\
\text { cognitions }\end{array}$ & $\begin{array}{l}\text { "I need to think } \\
\text { more objectively } \\
\text { when it comes } \\
\text { to men, not all } \\
\text { men are rude. } \\
\text { There are men } \\
\text { that are polite } \\
\text { and genuinely } \\
\text { courteous to } \\
\text { women" }\end{array}$ & $\begin{array}{l}\text { "I don't want } \\
\text { this problem to } \\
\text { keep dragging } \\
\text { me down, I want } \\
\text { to move on and } \\
\text { do other things } \\
\text { that are more } \\
\text { worthwhile in } \\
\text { my life" }\end{array}$ & $\begin{array}{l}\text { "I am committed to } \\
\text { let go of this pro- } \\
\text { blem, forgive him } \\
\text { and his conducts, } \\
\text { and move on. And I } \\
\text { would not listen to } \\
\text { him persuading me } \\
\text { to continue the } \\
\text { dating } \\
\text { relationship" }\end{array}$ & $\begin{array}{l}\text { "Even though this is } \\
\text { very difficult, now I can } \\
\text { understand why he } \\
\text { acted like that during } \\
\text { our dating } \\
\text { relationship" }\end{array}$ \\
\hline $\begin{array}{l}\text { Progress of } \\
\text { improvements }\end{array}$ & $\begin{array}{l}\text { Participant } 1 \text { felt } \\
\text { more } \\
\text { empowered } \\
\text { with the new } \\
\text { cognition after } \\
\text { the therapy }\end{array}$ & $\begin{array}{l}\text { Participant } 2 \\
\text { started to pursue } \\
\text { new career and } \\
\text { studies that she } \\
\text { liked to pursue }\end{array}$ & $\begin{array}{l}\text { Participant } 3 \text { had a } \\
\text { strong commitment } \\
\text { to forgive and } \\
\text { move on from the } \\
\text { perpetrator }\end{array}$ & $\begin{array}{l}\text { Participant } 4 \text { had a new } \\
\text { understanding about } \\
\text { the perpetrator's } \\
\text { mental health condition } \\
\text { and behavior during } \\
\text { their relationship }\end{array}$ \\
\hline \multicolumn{5}{|c|}{$\begin{array}{l}\text { Note. Participant } 4 \text { had a new understanding about the perpetrator's mental health condition and } \\
\text { behavior and could release and let go of the past. It was suspected that after listening to her } \\
\text { story and DV problems, and after consulting the story with experts such as psychologist, } \\
\text { during that period of their dating relationship, the perpetrator might have mental illness } \\
\text { problem himself that caused him to behave the way he did. }\end{array}$} \\
\hline
\end{tabular}

\section{Discussion}

The current research aimed to test the effectiveness of CBT intervention for reducing PTSD symptoms in women with dating violence (DV) experiences. CBT intervention protocol, that was given for 6 sessions (one session per week), is proven to be effective in reducing participants' PTSD symptoms. However, only two participants achieved full remission status. Improvements also occur in the other two participants, nonetheless, they were still in the mild range conditions of PTSD symptoms.

Previous research showed that CBT was an effective treatment for individuals or women with PTSD symptoms (Bisson et al., 2007; Foa et al., 2005; Resick et al., 2008). Compared with previous research on CBT for DV survivor such as from Rizzo et al. (2018), their research targeted participants' depressive symptoms, deficits in interpersonal skill and deficits in self-regulation. Contrary with research from Rizzo et al., the current research was targeting participants PTSD symptoms. Other research indicated that targeting both depressive symptoms and PTSD symptoms may be more beneficial and 
helpful for survivors (Iverson et al., 2011). Indeed, systematic review from Trabold et al. (2018) indicated that depressive and PTSD symptoms are two core features of mental health problems in the survivors that need to be targeted in therapy sessions. Secondly, compared to study from Rizzo et al. (2018), that used group-based format, the current research used individual therapy format. Rizzo et al. (2018) argued that the strength of group-based cognitive behavioral therapy was the effect of peer support that could act as treatment or therapeutic gain booster. Although this is true and cost-effective, the weakness of group-format is the lack of more in-depth CBT intervention and more indepth therapeutic alliance between client and therapist.

Compared with results of the previous research, in overall, CBT as treatment for women survivors of DV with PTSD symptoms is effective in helping to reduce these symptoms in the survivors. This can be seen in the overall reduction of 13 to 28 points in participants' or survivors' PCL-5 scores. As a reference, a 10 to 20 point change in PCL-5 scores represents a clinically significant change (Weathers et al., 2013). However, interpretation of PCL-5 scores needs to be handled very carefully (Weathers et al., 2013). Although there was a clinically significant change and reduction in PTSD symptoms in all participants, nevertheless, not all participants received remission from the symptoms and returned back to the normal range of functioning. After post-treatment, participant 2 and 4 were still in the category of mild range of PTSD and therefore, only participant 1 and 3 achieved remission from PTSD symptoms. Therefore, in comparison with previous research (Crespo \& Arinero, 2010; Iverson et al., 2011; Johnson et al., 2011; Reed \& Enright, 2006), the results of the current research are quite differ in terms of the efficacy of the treatment given to the women who are experiencing abuse from their partner. However, the current pilot research still yielded early promising results for women survivors of DV because of overall clinically significant reduction of PTSD symptoms in the survivors of DV.

There are several factors associated with the efficacy of CBT in helping women with DV or IPV experiences. According to Iverson et al., (2011) and Johnson et al. (2011), the positive outcomes that occurred to research participants after receiving CBT may be attributed to changes in cognition such as more accurate perceptions of experiences and more helpful thinking style that they learned from CBT sessions. Similar to above study, the participants in current study achieved more adaptive or more balanced thinking style and perceptions of problems after receiving individual CBT intervention for six sessions.

In this research, all participants experienced various types of dating violence (DV) including verbal, emotional, physical, and sexual violence or abuse. These DV occurrences and experiences lead to the experiences of PTSD symptoms or psychological traumatic experiences (Iverson et al., 2011). In line with previous research, survivors of DV were experiencing the feelings of hatred toward self and other people especially men, low selfesteem, and feelings of anger toward men in general (Iverson et al., 2011). Avoidance of internal and external stimuli that could remind them of the traumatic events were also experienced by the participants in this research. This kind of emotional response is also 
often called emotional suppression or emotional numbing, and is one of the core features of PTSD (Messman-Moore \& Long, 2003).

In terms of behavioral component of CBT, initially, participant 1 and 4 reported that they were having an increase in symptoms related to the re-experiencing of traumatic events, such as having flashbacks of traumatic memories after starting relaxation techniques for a while. However, this increase was not permanent and after continual practice of the techniques, the PTSD symptoms of the two participants were reduced quite significantly. Participant 2 and 3 did not report the same significant increase in PTSD symptoms after practicing relaxation techniques regularly at their own pace for a while. These findings were in line with research from Beck (2011). According to Beck (2011), some clients or patients could initially reported an increase in symptoms such as PTSD during the first few practices of techniques such as relaxation technique, due to the nature of automatic thoughts or maladaptive cognitions. These negative cognitions could resurface during relaxation practice and interfere with effective relaxation practice that is supposed to be beneficial to the clients or patients (Beck, 2011). Thus, according to Beck (2011), the role of a therapist is to give understanding and education to the clients that this kind of phenomenon might occur during the practice and to ensure that the clients would stick and comply to the practice of relaxation technique with consistency.

There were several factors that caused participant 2 and 4 to not achieving full remission status from PTSD symptoms. Firstly, the personality factor. According to Dunmore et al. (2001), certain person might have personality which is predisposed to be more vulnerable to psychological trauma. Given the right activating/triggering situation, the PTSD symptoms would emerge and become apparent in people with this kind of personality (Dunmore et al., 2001). It is suggested that participant 2 and 4 might have this kind of personality trait and therefore, when they experienced psychological trauma as a result of dating violence, the symptoms that they felt were more persistent and more difficult to disappear. Secondly, there was a situational factor affecting the symptoms of the two participants. This situational factor could contribute to exacerbate and perpetuate the PTSD symptoms that were being experienced by participant 2 and 4 at that time. The situational factor can be in a form of other stressor or problem that influenced the PTSD symptoms in a negative way (Ehlers \& Clark, 2000). Based on interview with participant 2 and 4, both of them had additional stressors in the form of academic stress and occupational or work-related stress. For participant 1 and 3 , the two participants that achieved remission from PTSD symptoms, the researcher and therapist attribute this achievement to the success in therapeutic alliance that was built step-by-step through rapport building, empathic understanding, and support from the therapist. Participant 1 and 3 also were more open when the therapist asked them questions and they were more cooperative when they participated in individual therapy sessions and when they did the cognitive and behavioral exercises both in the session and by themselves as homework assignment at home.

As a reflection, this study also had some limitations. Firstly, the current study did not employ control group as a comparison group to the experimental group or the group 
that received treatment protocol. Secondly, the study did not employ longitudinal study design in order to follow-up participants for several weeks or months post-therapy to see whether the treatment gain would be maintained. This was not done due to the time constraint of the researcher and therapist. Thirdly, the current study had very small sample size $(n=4)$ and therefore, more replications of the study with larger sample size are needed before generalization of results to IPV and DV survivor population in Indonesia can be made. Fourthly, therapist expectancy effect could potentially occur and create bias in the results, since the therapist and researcher came from the same research group in the institution. Nevertheless, the current study also had some strength in it. Firstly, the use of Cognitive-Behavioral Therapy as a method of therapy in this research was essential in order to ensure that the survivors of dating violence received an evidence-based therapy and were given excellent psychological care and intervention. Secondly, to the best of authors' knowledge, previous research about survivors of DV in Indonesia, its impacts, its consequences, and how to help these populations have been scarce. Thus, the current research gives a unique perspective and important contribution, not only to the body of knowledge, but also to the practical contribution in helping survivors of DV to cope, have resiliency, and to move on from such traumatic experiences.

\section{Conclusion}

The results of the research showed that Cognitive-Behavioral Therapy (CBT) can reduce PTSD symptoms in women, with dating violence (DV) experiences, who participated in this study. Through CBT intervention, participants in this study became more skilled in changing maladaptive cognitions into more positive and adaptive cognitions, especially in relation with previous traumatic DV experiences. This led to positive progress of improvements such as feeling of empowerment, new commitment to forgive perpetrator, and new resolution to move on and pursue new things. As a concluding statement, this pilot study gives a promising early result in helping survivors of DV using CognitiveBehavioral Therapy. However, these results should be handled and interpreted with care, because although all participants have clinically significant change and reduction in PTSD symptoms, only two participants achieved remission status and returned back to normal range of functioning.

\section{Implication}

For the direction for the future research, it is necessary to tackle the limitations mentioned above by employing control comparison group and using post-therapy follow-up test. Additionally, future research can focus on employing other therapies from Cognitive Behavioral Psychotherapies cluster such as Cognitive Processing Therapy, Acceptance and Commitment Therapy, or Rational-Emotive Behavioral Therapy. Future research can also focus on employing other therapies such as Behavioral Activation, Writing Therapy or Neuro-Linguistic Programming and to see the comparison and efficacies between these therapies to survivors of DV. Other than that, replication of current study with larger 
sample size and employing Randomized-Controlled Trial (RCT) protocol are also necessary. Fourthly, in order to avoid therapist and/or experimenter expectancy effect, it is necessary to employ blind-experiment protocol such as between therapist and researcher, where the main researcher and therapist do not know each other during the course of intervention sessions. Lastly, future research can also focus on other dimensions or variables that are affected by dating violence phenomenon such as survivors' psychological well-being (PWB), resiliency, self-esteem or meaning of life in light of such traumatic experiences during dating relationships or during/after a course of psychological treatment such as CBT has been given to them.

\section{Acknowledgments}

The authors would like to thank The Directorate of Research and Community Service - Ministry of Research, Technology and Higher Education of Indonesia (DRPM - Kemenristekdikti) who had helped in funding the research. The authors would also like to thank Shirley Angelin Kusuma, Psikolog for her contribution in providing supervision throughout the intervention sessions.

\section{Funding}

This paper was a part of the research grants from DRPM - Kemenristekdikti with the title GenderBased Model of Prevention and Protection of Dating Violence from the Integrative Holistic PsychoEcological Perspective in Central Java in the third year of 3-year plan, in 2018.

\section{Conflict of interests}

The authors declare no conflict of interests in this article.

\section{Authors' contributions}

The first author, SP was responsible for the overall content of the article. This encompasses: drafting the original manuscript, doing literature review, searching for the instrument, collecting data, and the writing process of the original and final version of the manuscript. SW was responsible for conceptualizing the original research ideas, contributing in literature review and conceptualizing and writing the discussion section. AIRH was responsible for data analysis and the results section. All authors read and approved the final version of the manuscript.

\section{Orcid ID}

Stefanus Perangin-Angin

Sutarto Wijono

: https://orcid.org/0000-0001-8286-4037

Arianti Ina Restiani Hunga

: https://orcid.org/0000-0003-2154-6056

: https://orcid.org/0000-0003-1627-2353

\section{References}

Ager, R. D. (2020). A qualitative study of intimate partner violence from a cognitivebehavioral perspective. Journal of Interpersonal Violence, 35(23-24), 5198-5227. https://doi.org/10.1177/0886260517719902

Alleyne-Green, B., Grinnell-Davis, C., Clark, T. T., Quinn, C. R., \& Cryer-Coupet, Q. R. (2016). Father involvement, dating violence, and sexual risk behaviors among a national sample of adolescent females. Journal of Interpersonal Violence, 31(5), 810 830. https://doi.org/10.1177/0886260514556762 
Baldwin, K. (2012). Factbox: The worst and best G20 countries for women. Thomson Reuters Foundation. https://doi.org/http://news.trust.org/item/20120613010100-sk134/

Barlow, D. H. (2008). Clinical handbook of psychological disorders: A step-by-step treatment manual (4th ed.). The Guilford Press.

Beck, A. T., \& Dozois, D. J. A. (2011). Cognitive therapy: Current status and future directions. Annual Review of Medicine, 62, 397-409. https://doi.org/10.1146/annurevmed-052209-100032

Beck, J. (2011). Cognitive behavior therapy: Basics and beyond (2nd ed.). Guilford Press.

Bell, M. E., Cattaneo, L. B., Goodman, L. A., \& Dutton, M. A. (2008). Assessing the risk of future psychological abuse: Predicting the accuracy of battered women's predictions. Journal of Family Violence, 23(2), 69-80. https://doi.org/10.1007/s10896007-9128-5

Bisson, J. I., Ehlers, A., Matthews, R., Pilling, S., Richards, D., \& Turner, S. (2007). Psychological treatments for chronic post-traumatic stress disorder: Systematic review and meta-analysis. British Journal of Psychiatry, 190, 97-104. https://doi.org/10.1192/bjp.bp.106.021402

Blevins, C. A., Weathers, F. W., Davis, M. T., Witte, T. K., \& Domino, J. L. (2015). The posttraumatic stress disorder checklist for DSM-5 (PCL-5): Development and initial psychometric evaluation. Journal of Traumatic Stress, 28(6), 489-498. https://doi.org/10.1002/jts.22059

Bovin, M. J., Marx, B. P., Weathers, F. W., Gallagher, M. W., Rodriguez, P., Schnurr, P. P., \& Keane, T. M. (2016). Psychometric properties of the PTSD checklist for Diagnostic and Statistical Manual of Mental Disorders-Fifth Edition (PCL-5) in veterans. Psychological Assessment, 28(11), 1379-1391. https://doi.org/10.1037/pas0000254

Braun, V., \& Clarke, V. (2006). Using thematic analysis in psychology. Qualitative Research in Psychology, 3(2), 77-101. https://doi.org/10.1191/1478088706qp063oa

Breiding, M. J., Black, M. C., \& Ryan, G. W. (2008). Prevalence and risk factors of intimate partner violence in eighteen U.S. states/territories in 2005. American Journal of Preventive Medicine, 34(2), 112-118. https://doi.org/10.1016/j.amepre.2007.10.001

Breiding, M. J., Chen, J., \& Black, M. C. (2014). Intimate partner violence in the United States - 2010. In Centers for Disease Control and Prevention.

Calvete, E., Fernández-González, L., Orue, I., \& Little, T. D. (2018). Exposure to family violence and dating violence perpetration in adolescents: Potential cognitive and emotional mechanisms. Psychology of Violence, 8(1), 67-75. https://doi.org/10.1037/vio0000076

Carrell, S. E., \& Hoekstra, M. (2012). Family business or social problem? The cost of unreported domestic violence. Journal of Policy Analysis and Management, 31(4), 861875. https://doi.org/10.1002/pam.21650

Centers for Disease Control and Prevention. (2014). Understanding intimate partner violence: Fact sheet. In Centers for Disease Control and Prevention.

http://www.cdc.gov/ncipc/dvp/ipv_factsheet.pdf 
Cougle, J. R., Resnick, H., \& Kilpatrick, D. G. (2009). A prospective examination of PTSD symptoms as risk factors for subsequent exposure to potentially traumatic events among women. Journal of Abnormal Psychology, 118(2), 405-411. https://doi.org/10.1037/a0015370

Crespo, M., \& Arinero, M. (2010). Assessment of the efficacy of a psychological treatment for women victims of violence by their intimate male partner. Spanish Journal of Psychology, 13(2), 849-863. https://doi.org/10.1017/S113874160000250X

Dunmore, E., Clark, D. M., \& Ehlers, A. (2001). A prospective investigation of the role of cognitive factors in persistent Posttraumatic Stress Disorder (PTSD) after physical or sexual assault. Behaviour Research and Therapy, 39(9), 1063-1084. https://doi.org/10.1016/S0005-7967(00)00088-7

Ehlers, A., \& Clark, D. M. (2000). A cognitive model of posttraumatic stress disorder. Behaviour Research and Therapy, 38(4), 319-345. https://doi.org/10.1016/S00057967(99)00123-0

Exner-Cortens, D., Eckenrode, J., \& Rothman, E. (2013). Longitudinal associations between teen dating violence victimization and adverse health outcomes. Pediatrics, 131(1), 71-78. https://doi.org/10.1542/peds.2012-1029

Foa, E. B., Hembree, E. A., Cahill, S. P., Rauch, S. A. M., Riggs, D. S., Feeny, N. C., \& Yadin, E. (2005). Randomized trial of prolonged exposure for posttraumatic stress disorder with and without cognitive restructuring: Outcome at academic and community clinics. Journal of Consulting and Clinical Psychology, 73(5), 953-964. https://doi.org/10.1037/0022-006X.73.5.953

Folger, S. F., \& Wright, M. O. D. (2013). Altering risk following child maltreatment: Family and friend support as protective factors. Journal of Family Violence, 28, 325-337. https://doi.org/10.1007/s10896-013-9510-4

Haller, M., Norman, S. B., Cummins, K., Trim, R. S., Xu, X., Cui, R., Allard, C. B., Brown, S. A., \& Tate, S. R. (2016). Integrated cognitive behavioral therapy versus cognitive processing therapy for adults with depression, substance use disorder, and trauma. Journal of Substance Abuse Treatment, 62, 38-48. https://doi.org/10.1016/j.jsat.2015.11.005

Han, S. C., \& Margolin, G. (2016). Intergenerational links in victimization: Prosocial friends as a buffer. Journal of Child and Adolescent Trauma, 9, 153-165. https://doi.org/10.1007/s40653-015-0075-7

Hayes, S. C., Strosahl, K. D., \& Wilson, K. G. (1999). Acceptance and commitment therapy: An experiential approach to behavior change. The Guilford Press.

Hébert, M., Daspe, M. È., Lapierre, A., Godbout, N., Blais, M., Fernet, M., \& Lavoie, F. (2019). A meta-analysis of risk and protective factors for dating violence victimization: The role of family and peer interpersonal context. Trauma, Violence, and Abuse, 20(4), 574-590. https://doi.org/10.1177/1524838017725336

Huecker, M. R., \& Smock, W. (2019). Domestic Violence. StatPearls Publishing. https://www.ncbi.nlm.nih.gov/books/NBK499891/

Iverson, K. M., Gradus, J. L., Resick, P. A., Suvak, M. K., Smith, K. F., \& Monson, C. M. (2011). Cognitive-behavioral therapy for PTSD and depression symptoms reduces 
risk for future intimate partner violence among interpersonal trauma survivors. Journal of Consulting and Clinical Psychology, 79(2), 193-202. https://doi.org/10.1037/a0022512

Iverson, K. M., Lester, K., \& Resick, P. A. (2011). Psychosocial treatments. In W. Benedek (Ed.), Clinical manual for the management of PTSD (pp. 157-203). American Psychiatric Publishing, Inc.

Jennings, W. G., Okeem, C., Piquero, A. R., Sellers, C. S., Theobald, D., \& Farrington, D. P. (2017). Dating and intimate partner violence among young persons ages 15-30: Evidence from a systematic review. Aggression and Violent Behavior, 33, 107-125. https://doi.org/10.1016/j.avb.2017.01.007

Johnson, D. M., Zlotnick, C., \& Perez, S. (2011). Cognitive behavioral treatment of PTSD in residents of battered women's shelters: Results of a randomized clinical trial. Journal of Consulting and Clinical Psychology, 79(4), 542-551. https://doi.org/10.1037/a0023822

Johnson, R. B., Onwuegbuzie, A. J., \& Turner, L. A. (2007). Toward a definition of mixed methods research. Journal of Mixed Methods Research, 1, 112-133. https://doi.org/10.1177/1558689806298224

Komnas Perempuan. (2015). Kekerasan terhadap perempuan: Negara segera putus impunitas pelaku, catatan KTP 2014. https://www.komnasperempuan.go.id/file/pdf_file/Catatan Tahunan/13.PP5_CATAHU-2015.pdf

Komnas Perempuan. (2016). Kekerasan terhadap perempuan meluas: Negara urgen hadir hentikan kekerasan terhadap perempuan di ranah domestik, komunitas dan negara, catatan KTP tahun 2015. https://www.komnasperempuan.go.id/file/pdf_file/Catatan Tahunan/14.PP5_CATAHU 2016.pdf

Komnas Perempuan. (2017). Labirin kekerasan terhadap perempuan: Dari gang rape hingga femicide, alarm bagi negara untuk bertindak tepat, catatan KTP 2016.

https://www.komnasperempuan.go.id/file/pdf_file/2017 Siaran Pers/Lembar Fakta Catahu 2017.pdf

Komnas Perempuan. (2018). Tergerusnya ruang aman perempuan dalam pusaran politik populisme, catatan KTP 2017.

https://www.komnasperempuan.go.id/file/pdf_file/2018/Publikasi/Catatan Tahunan Kekerasan Terhadap Perempuan 2018.pdf

Krause, E. D., Kaltman, S., Goodman, L., \& Dutton, M. A. (2006). Role of distinct PTSD symptoms in intimate partner reabuse: A prospective study. Journal of Traumatic Stress, 19(4), 507-516. https://doi.org/10.1002/jts.20136

Kristoper, I. T., Wijono, S., \& Engel, J. D. (2019). Counseling as a method of psychological reconciliation for victims of dating violence. Buletin Psikologi, 27(2), 136-147. https://doi.org/10.22146/buletinpsikologi.44792

Kuijpers, K. F., van der Knaap, L. M., \& Winkel, F. W. (2012). PTSD symptoms as risk factors for intimate partner violence revictimization and the mediating role of victims' violent behavior. Journal of Traumatic Stress, 25(2), 179-186.

https://doi.org/10.1002/jts.21676 
Max, W., Rice, D. P., Finkelstein, E., Bardwell, R. A., \& Leadbetter, S. (2004). The economic toll of intimate partner violence against women in the United States. Violence and Victims, 19(3), 259-272. https://doi.org/10.1891/vivi.19.3.259.65767

Messman-Moore, T. L., \& Long, P. J. (2003). The role of childhood sexual abuse sequelae in the sexual revictimization of women: An empirical review and theoretical reformulation. Clinical Psychology Review, 23(4), 537-571. https://doi.org/10.1016/S0272-7358(02)00203-9

Miller, E., Jones, K. A., \& McCauley, H. L. (2018). Updates on adolescent dating and sexual violence prevention and intervention. Current Opinion in Pediatrics, 30(4), 466-471. https://doi.org/10.1097/MOP.0000000000000637

Murray, J. (2013). But I love him: Protecting your teen daughter from controlling, abusive dating relationships. Harper Collins Publishers.

Perangin-Angin, S., Wijono, S., \& Hunga, A. I. R. (2019). Pola pengalaman depresi perempuan yang mengalami kekerasan dalam berpacaran: Kajian perspektif $\begin{array}{llll}\text { cognitive-behavioural. Buletin } & \text { Psikologi, }\end{array}$ https://doi.org/10.22146/buletinpsikologi.40450

Reed, G. L., \& Enright, R. D. (2006). The effects of forgiveness therapy on depression, anxiety, and posttraumatic stress for women after spousal emotional abuse. Journal of Consulting and Clinical Psychology, 74(5), 920-929. https://doi.org/10.1037/0022006X.74.5.920

Resick, P A, Monson, C. M., \& Chard, K. M. (2016). Cognitive processing therapy for PTSD: A comprehensive manual. The Guilford Press.

Resick, P A, Monson, C. M., \& Rizvi, S. L. (2008). Posttraumatic stress disorder. In D. H. Barlow (Ed.), Clinical handbook of psychological disorders: A step by-step treatment manual (4th ed., pp. 65-122). The Guilford Press.

Resick, Patricia A., Galovski, T. E., Uhlmansiek, M. O. B., Scher, C. D., Clum, G. A., \& Young-Xu, Y. (2008). A randomized clinical trial to dismantle components of cognitive processing therapy for posttraumatic stress disorder in female victims of interpersonal violence. Journal of Consulting and Clinical Psychology, 76(2), 243-258. https://doi.org/10.1037/0022-006X.76.2.243

Rivara, F. P., Anderson, M. L., Fishman, P., Bonomi, A. E., Reid, R. J., Carrell, D., \& Thompson, R. S. (2007). Healthcare utilization and costs for women with a history of intimate partner violence. American Journal of Preventive Medicine, 32(2), 89-96. https://doi.org/10.1016/j.amepre.2006.10.001

Rizzo, C. J., Joppa, M., Barker, D., Collibee, C., Zlotnick, C., \& Brown, L. K. (2018). Project date SMART: a dating violence (DV) and sexual risk prevention program for adolescent girls with prior DV exposure. Prevention Science, 19(4), 416-426. https://doi.org/10.1007/s11121-018-0871-z

Sánchez-Jiménez, V., Muñoz-Fernández, N., \& Ortega-Rivera, J. (2018). Efficacy evaluation of "Dat-e Adolescence": A dating violence prevention program in Spain. PLoS ONE, 13(10), 1-23. https://doi.org/10.1371/journal.pone.0205802 
Shorey, R. C., Cornelius, T. L., \& Bell, K. M. (2008). A critical review of theoretical frameworks for dating violence: Comparing the dating and marital fields. Aggression and Violent Behavior, 13(3), 185-194. https://doi.org/10.1016/j.avb.2008.03.003

Todman, J. B., \& Dugard, P. (2001). Single-case and small-n experimental designs: A Practical guide to randomization tests. Psychology Press.

Trabold, N., McMahon, J., Alsobrooks, S., Whitney, S., \& Mittal, M. (2018). A systematic review of intimate partner violence interventions: State of the field and implications for practitioners. Trauma, Violence, and Abuse, 1-15. https://doi.org/10.1177/1524838018767934

Vézina, J., Hébert, M., Poulin, F., Lavoie, F., Vitaro, F., \& Tremblay, R. E. (2011). Risky lifestyle as a mediator of the relationship between deviant peer affiliation and dating violence victimization among adolescent girls. Journal of Youth and Adolescence, 40, 814-824. https://doi.org/10.1007/s10964-010-9602-x

Vézina, J., Hébert, M., Poulin, F., Lavoie, F., Vitaro, F., \& Tremblay, R. E. (2015). History of family violence, childhood behavior problems, and adolescent high-risk behaviors as predictors of girls' repeated patterns of dating victimization in two developmental periods. Violence Against Women, 21(4), 435-459. https://doi.org/10.1177/1077801215570481

Weathers, F. W., Litz, B. T., Keane, T. M., Palmieri, P. A., Marx, B. P., \& Schnurr, P. P. (2013). The PTSD Checklist for DSM-5 (PCL-5). In National Center for PTSD. National Center for PTSD. https://doi.org/10.1037/t02622-000

World Health Organization. (2013). Global and regional estimates of violence against women: Prevalence and health effects of intimate partner violence and non-partner sexual violence. http://www.who.int/reproductivehealth/publications/violence/9789241564625/en/ 